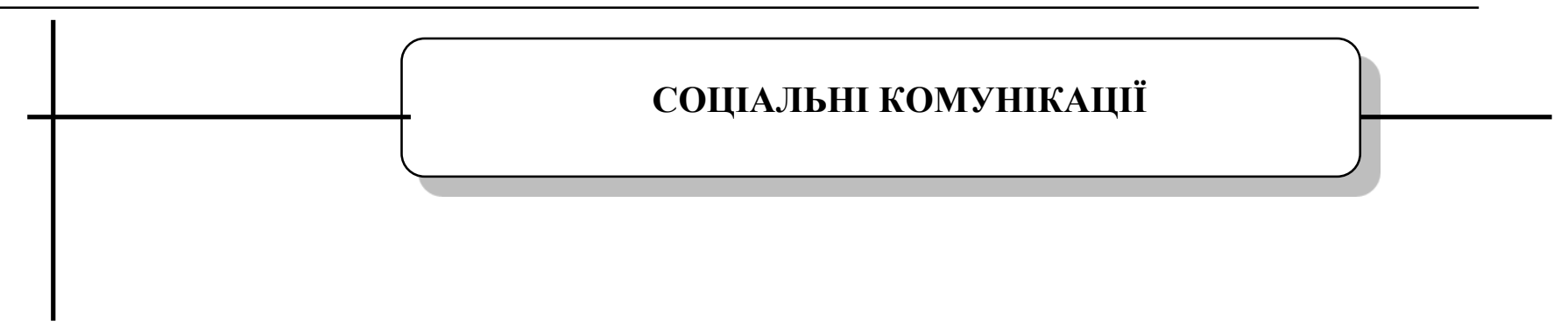

UDC [007:304]:004.01

DOI: 10.15587/2313-8416.2018.127525

\title{
SECTORAL TERMINOLOGY OF THE UKRAINIAN TRADE ACTIVITY: MAIN ASPECTS OF FUNCTIONING
}

\section{(C) O. Shevchenko}

У статті науково обтрунтовуються сучасні тенденції функціонування базових ключових термінів торговельної галузі Украӥни, увага акцентується на термінах документознавчого спрямування та іншомовного походження, пов'язаних з торговельною документацією; до розгляду запропоновано процеси термінологічного супроводу електронної комериіі

Ключові слова: галузева документація, торговельна документація, торгівля, поняття, терміни, визначення, інформаційний ресурс, комерція, документаційне забезпечення

\section{Introduction}

The study of any sectoral documentation requires an integrated and systematic approach to understanding the basic key concepts. We believe that such concepts should include: informational infrastructure of the industry (knowledge, information, documents); communication environment of the industry (including document communications); document production of the industry (documentation, document flow). The specificity of information and document production is determined by the industry to which such production is directed. The lack of theoretically substantiated formulations in the documentary orientation of this study requires careful observation of the basic terms of the subject area. The limitation of traditional document-based approaches and the unresolved theoretical problems negatively affect the optimization of information and documentation processes.

\section{Literature review}

Ukrainian document specialists did not translate and analyze professional trade documentation. The general positions of the terminology research vectors were pointed out by N. M. Kushnarenko, V. V. Bezdrabko, G. M. Shvetsova-Vodka, M. I. Senchenko, L. Ya. Filipova and others. The theoretical, practical aspects of the competitiveness of trade enterprises are devoted to the monograph by N. Tyagunova and V. Boin [1]. Noteworthy is the monograph by MV Komova «The Ukrainian Documentation Terminology: The Ways of Creation and Functional Peculiarities». In three chapters, the author has researched the peculiarities of the formation and development of Ukrainian terminology, discovered the genetic sources of the formation and analysis of the lexicogrammatical composition of terminology, studied the regularities of normalization document terminology system [2].

\section{The aim and objectives of the study}

Aim of research - to find out the main aspects of the functioning of the sectoral terminology of trade activity in Ukraine. were set:

To achieve this objective, the following tasks

1. to uncover peculiarities of the functioning of the key concepts of the Ukrainian trade sector.

2. define the terminological content of branch basic concepts, namely: "trade documentation", "commercial documentation on electronic media", "commerce", "trade", "information resource", etc.

\section{Materials and methods}

A generalization method was used to penetrate into the essence of the trading activity terminology; theoretical method - for the analysis of scientific resources.

\section{Result}

The components of the professional documentation can be divided into six blocks, namely: basic (socially significant), socio-political, economic, financial, legal and natural-scientific. Each of these systems may have their own subsystems, which, in turn, are independent documentation systems according to their structural components, as Yu. I. Palekha says. The author defines the place of the commercial documentation, as a subsystem, exactly within the limits of the economic block [3].

It is important to say that for each system of documentation, not only interconnection and mutual preconditionality is typical, but also often interpenetration into each other, because all areas and levels of government in the state are interconnected. The combination of various blocks, systems (subsystems) of documentation is determined by the needs of practical activity or the continuity of the already developed classification schemes. The 
blocks of managerial (corporate) and sectoral (professional) documentation systems constitute a unified system of documentation for a certain area of activity. This made it possible to distinguish in the structure of sectoral document science the theoretical and practical direction the trade documentation. In the system of documental scientific disciplines, trade document science belongs to economic document science. In addition, it relates to industry documentation and it is its subsystem. At the level of the conceptual apparatus, the issues of the genesis and the revealed patterns, it is associated with general documentation science. This approach allows us to determine the principles of the trading documentation system identification, to characterize the elemental (document) filling of the system; to elicit intra- and intersystem relationships; to analyze the functional purpose of the trade industry documentation system. Documentation support for the trading industry is a subsystem of the economic system of documentation support, which is at the same time a subsystem of the industry component of the general documentation system.

The terminology of document terms is based on current standards:

DSTU 2392-94,

DSTU 2394-94,

DSTU 2395-94,

DSTU 2398-94,

DSTU 2732:2004,

DSTU 3017-95,

DSTU 3148-95,

DSTU 3843-99,

DSTU 3966-2000,

DSTU 4331:2004

DSTU ISO 5127:2007,

STU 7448:2013, etc.

Also it is important to clarify the industry, which is investigated from a documentary point of view, focusing on the most commonly used industry terms: "commerce", "trade", "commercial activity", "trading activity", "commercial enterprise", "commercial process" and others that characterize the structure of the communication environment of trading activity.

Here are the definitions of the trading activity terms. Commerce is a trade and related affairs. In the broad sense of the word, the commerce is an entrepreneurial activity, in the narrow - trade and intermediary activity [4, p. 409].

Commercial activity is a function of entrepreneurial business, connected with the provision of a set of actions for the optimization of organizational and technological trade operations, which in the process of sale and purchase of goods and services contribute to accelerating their turnover in the process of bringing them to the end user, provided that they meet demand.

Trade is a type of economic activity in the field of goods turnover and their promotion from producer to consumer in the form of purchase and sale and provision of related services. Trade is the purchase and sale of goods [5].

Trading activity is an initiative, independent activity of legal entities and citizens on the purchase and sale of consumer goods for the purpose of profit $[6$, p. $69 ; 19$, p. 40-42].
The terms "commerce", "trade", "commercial activity", "trading activity" are based on DSTU 4303:2004 "Retail and Wholesale Trade. Terms and Definitions", which includes 210 terms and is based on DSTU 2681-94 "Metrology. Terms and definitions", DSTU 3144-95 "Codes and encoding of information. Bar coding. Terms and Definitions" and DSTU 3993-2000 "Commodity. Terms and Definitions", taken from industry-based terminology dictionaries [7].

Today, researchers sometimes identify the terms "trade" and "commerce", however, according to experts, there is a difference between them. Trade is the form of commerce existence and reflects the sales relations that are belong to commerce. The result of trade as a sphere of commercial activity is the sale of products. A specific feature of trading is the product owner change, also there is a need to physically move the product and change the communication environment [8, p. 51]. Consequently, commerce is a trade and intermediary activity, a sale or promotion of goods and services; commercial activity is the organization and management of commercial processes and operations related to commodity-money exchange. The term "commerce" translated from Latin means trade. In the broad sense, commerce is understood as any activity the purpose of which is profit [9, p. 19].

The basis of commercial activity is the organization of commercial processes, operations and their management. The main task of commerce - to enable goods and services exchange in cash. It should be noted that commercial activity does not cover operations that are related to the continuation of the production process in the sphere of circulation: distribution, storage, packaging, goods supply, sorting of goods, and the formation of lines [10]. The objects of commercial activity are goods and services. The author shares the scientific positions of V. V. Apopii and his authoring team.

Trade is interpreted as "the form of commoditymoney exchange and the sphere of goods and services circulation, the development and functioning of trade is conditioned by the existence of commodity production, which implies the need for commodity-money exchange and bringing goods from the sphere of production to the sphere of consumption" [11].

The terms of the document orientation should be considered as those, which are directly related to the trade documentation.

Thus, the definition "documentation support" in DSTU 2732:2004 "The workflow management and archive business" is interpreted as an activity that ensures the documentation and organization of work with official documents [12].

The term "documentation support" relates to information provision, which is a multicomponent concept, which includes information support, information technology, information activities, information systems and information resources. It is important to emphasize the legislative consolidation of the main terms of information support: information technology, information activities, information system, information resources on the basis of the Laws of Ukraine "On the National Program of Informatization" No. 74/98-VR of February 4, 1998 and "On Information" No. 2657-XII of October 2, 1992, GOST 34003-90 "Information technology. A set of 
standards for automated systems. Automated systems. Terms and Definitions".

The State Classifier of Administrative Records (SCAR) contains the class of trade (code 09) and foreign trade documentation (code 10) and provides the definition of a unified trading documentation system as a system of documentation used to carry out trade management tasks and a unified system of foreign trade documentation as a documentation system used for carrying out tasks of foreign trade activity [13]. Taking into account the above interpretation of the term "commerce", we can identify terminological concepts "commercial documentation" and "commercial documentation", but the term "commercial documentation" is not currently used in sectoral documentation, instead the term "commercial documents" is used.

The international standard ISO 9001, the analogue of which in Ukraine is DSTU ISO 9004-2-96 "Quality management and elements of the quality system" and DSTU 15467-79 "Quality management of products. Fundamental principles. Terms and definitions", is of great importance for the sectoral terminology of trade. However, it should be noted that the documentation required for the components of the quality management system (technical, economic, etc.) is not included [14, 15].

There are some difficulties with the use of terms of foreign origin, the translation of which is significantly different. Sometimes it is difficult to distinguish the professional word from the commonly used one. For Ukrainian terms, the trade direction is characterized by a certain synonymity during the translation, not all the words being studied have an unambiguous translation, etc.

The point to note is that the basis of the new model of modern business is electronic commerce, therefore the electronic document becomes one of the essential levers of the economy and an integral part of the external documentation environment of Ukrainian trade activity. The term "electronic commerce" is defined as social relations that arise in the process of concluding or executing a deal for the supply or sale of electronic goods, the execution of works, the provision of electronic services and other actions aimed at profit, the creation of obligations with the use of information and telecommunication systems if, as a result of the said actions, the obligations of property nature arise in the participants of such relations, the conditions for the conclusion of electronic contracts are borrowed from the Law of Ukraine No. 675-VIII of 3 September March 2015 "On e-commerce" [16]. The term "electronic document", which has three structural components: content, details and carrier, which in the information infrastructure of commercial activity are important means of document communications, is taken as the basis for the definition of the term "trade documentation on electronic media of information". In accordance with these characteristics, the document essence of the term "commercial documentation on electronic media" is suggested to be determined in an accessible form with an arbitrary list of necessary requisites and recommendations on the possibility of adding other details. In the narrow sense, the interpretation of the term is not sufficiently explored; the terminological content of the industry basic concepts that are the basis of the terminology of the Ukrainian economy should be carefully studied.

Thus, when documenting an order on websites, there are some difficulties, as the functionality of website terminology has some disadvantages:

- absence of full-text search and text links for additional information;

- the search engine does not take into account the morphology of words, because the word change distorts the results, the synonyms are not used and the help is not offered, but there is the possibility of choosing the language of information perception.

As to the term "information resources", the scientist R. Marutian says: "... there is no cross functional definition of the term "information resource", the term itself is actively used in the theory and practice of various sciences" [17]. The scientist A. V. Lipinska uses the term "commercial information resources" containing information about companies, firms, etc. [18]. In the Law of Ukraine "On Information" No. 2657-XI dated October 2, 1992 , it is specified that "the information resources of Ukraine include all the belonging information, regardless of content, forms, time and place of creation", in particular sectoral ones [19]. At the same time, it should be noted: electronic resources are a variety of information resources, as evidenced by H. V. Shemaieva, considering them as a complex of various types of information resources in electronic form [20].

\section{Conclusions}

1. Consequently, the issues of the terminological provision of Ukrainian trade activity documentary support are solved only fractionally, the processes of trade documenting are highlighted fragmentarily, so they need to be refined in accordance with the needs of the industry. In the narrow sense, the interpretation of terms are not explored well, the terminological content of the industry basic concepts that are the basis of the terminology of the Ukrainian economy is needed to be thoroughly studied. Absence in Ukraine of a reliable system of standards for the functioning of e-commerce and the requirements for its text content; the terminology of trading concepts, which begin with the most general and end with specific key concepts of the industry, is important for finding the necessary product.

2. The analysis of the studied terms definitions allowed to systematize the basic approaches to the consideration of the basic terms, among which: "trade documentation", "commercial documentation on electronic media", "commerce", "trade", "commercial activity", "trading activity", "information security", "document support", "electronic document", "document communication", etc.

\section{References}

1. Tyagunova N. M. Competitiveness of trade enterprises: monograph. Poltava: RVV PUET, 2010.

2. Komova M. V. Ukrainian document terminology: ways of creation and functional features [Modern trends in retail network in Ukraine ]. Lviv: Lvivska Politechnika Publishing House, 2011. 
3. Palekha, Yu. Y. Puty razvytyia nauky o dokumente. URL: http://www.dilo.kiev.ua/naukovi-praci-puti-razvitiya-nauki-odokumente.html

4. Velykyi tlumachnyi slovnyk suchasnoi ukrainskoi movy. Kyiv; Irpin: Perun, 2009.

5. Fynansovo-kredytnyi entsyklopedycheskyi slovar. Moscow: Fynansy y statystyka, 2002. 1165 p.

6. Zakonodavstvo Ukrainy pro torhivliu i torhovelne obsluhovuvannia : zb. ofits. tekstiv zakoniv. Kyiv : Tsentr uchb. lit., 2012. [in Ukrainian].

7. Pushkar, A. Y. Stratehycheskoe upravlenye razvytyem elektronnoho byznesa y ynformatsyonnykh resursov predpryiatyia (modely, stratehyy, mekhanyzmy): nauch. yzd. Kharkov : Yzd. KhNEU, 2005. 2011.

8. Medzhybovska, N. S. Formuvannia elektronnoho postachannia promyslovykh pidpryiemstv: monohrafiia. Odesa: Palmira,

9. Zakonodavstvo Ukrainy pro torhivliu i torhovelne obsluhovuvannia : zb. ofits. tekstiv zakoniv. Kyiv: Tsentr uchb. lit., 2012.

10. Horshkova, L. V. Planyrovanye na predpryiatyiakh torhovly. Vladyvostok: Yzd-vo RDU, 2007.

11. Artamonova, N. O. Systema informatsiinoho zabezpechennia medychnoi nauky v Ukraini: monohrafiia. Kharkiv: Miskdruk, 2010.

12. DSTU 2732:2004. Dilovodstvo y arkhivna sprava. Terminy ta vyznachennia poniat [Product innovative policy]. URL: http://www.archives.gov.ua/Law-base/Standards

13. Derzhavnyi klasyfikator upravlinskoi dokumentatsii Ukrainy (DKUD) (n.d.). DK 010-98. Besplatnaia byblyoteka: sait. Elektron. tekst. dani. [B. m.]. URL: http://dstu-biblio.3dn.ru

14. Tyshchenko, A. Prydbannia y oblik tovariv na pidpryiemstvi . Dilovodstvo y dokumentoobih, 2011.

15. Transportni dokumenty. Konteinerni perevezennia. DUKE ACTIVE : sait. Elektron. tekst. dani. [Odesa], 2016. URL: http://www.duke-active.com/ru/pages.php?pg=20

16. Pro elektronnu komertsiiu: Zakon Ukrainy № 675 Verkhovna Rada Ukrainy: ofits. veb-portal. [Kyiv], 1994-2016. URL: http://zakon3.rada.gov.ua/laws/show/675-19

17. Marutian, R. Informatsiini resursy: novi pidkhody do vyznachennia poniattia . Suchasna ukrainska polityka: polityky i politolohy pro nei : nauk. vyd. Ukr. akad. polit. nauk, Ukr. tsentr polit. menedzhmentu. Kyiv, 2009.

18. Lipinska, A. V. () Formuvannia informatsiinoi kultury maibutnikh dokumentoznavtsiv. Teoriia ta metodyka navchannia matematyky, fizyky, informatyky: zb. nauk. pr. :Nats. metalurh. akad. Ukrainy, 2011.

19. Pro informatsiiu: Zakon Ukrainy № 2657-XII Elektron. tekst. dani. Kyiv, 1992. URL: http://zakon5.rada.gov.ua/laws/show/2657-12

20. Shemaieva, H. V. Elektronni resursy bibliotek Ukrainy v systemi naukovykh komunikatsii : monohrafiia. M-vo kultury i turyzmu Ukrainy, Kharkiv. derzh. akad. kultury. Kharkiv: KhDAK, 2008.

Дата надходження рукопису 30.01.2018

Elena Shevchenko, Doctor of Science in Social Communications, Professor, Department of Information Activity and Media Communications, Odessa National Polytechnic University, Shevchenko ave., 1, Odessa, Ukraine, 65044

E-mail: o.v.shevchenko1968@gmail.com 